*akls View/Frint Document Cover Sheet tow

This document was retrieved from the Boeing ISEARCH System.

Accession \#: D196054920

Document \#: SD-WM-ER-507

Title/Desc:

TANK 241S111 HEADSPACE GAS \& VAPOR CHARACTERIZATION RESULTS FOR SAMPLES COLLECTED IN $3 / 1995$ 


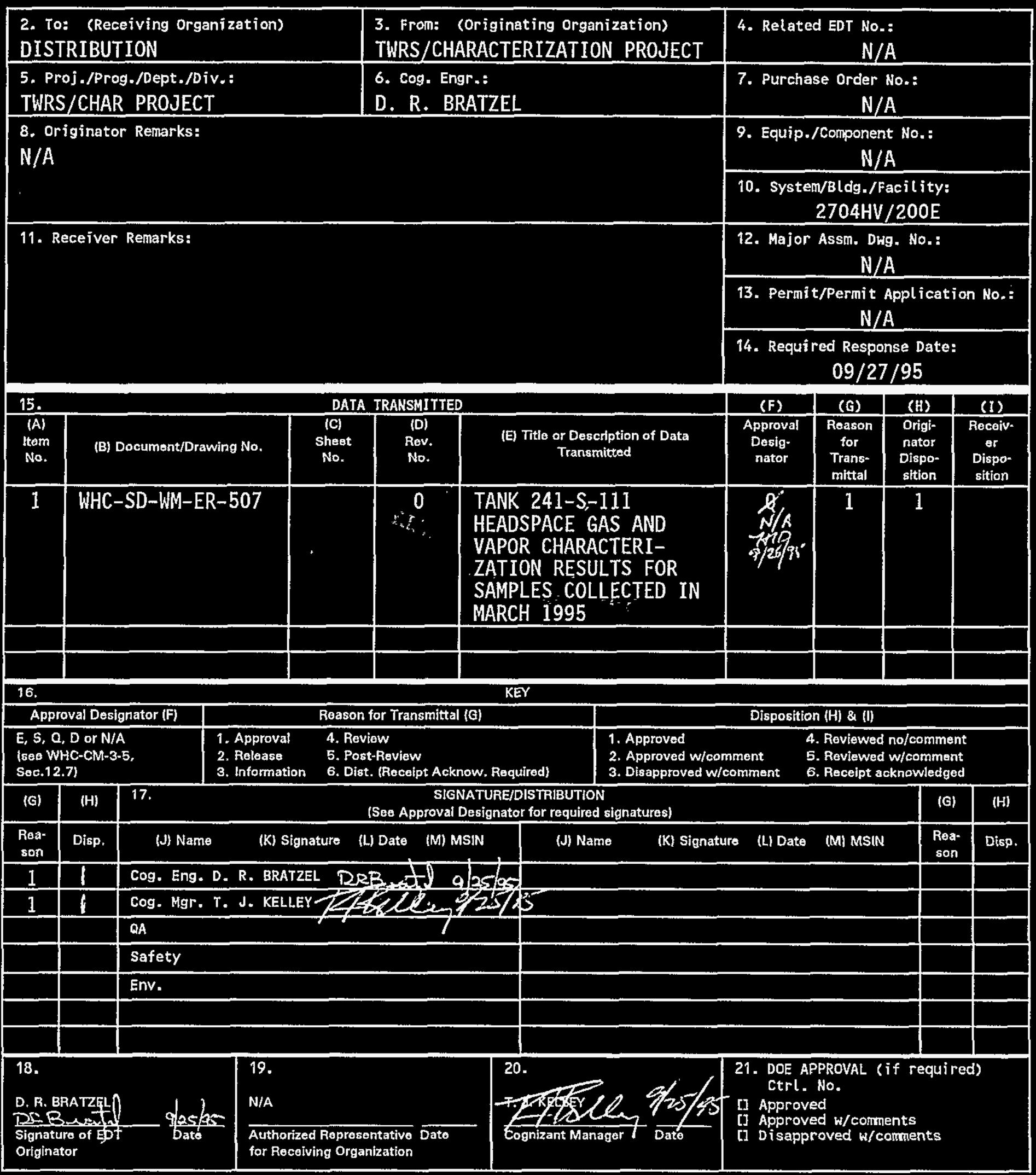




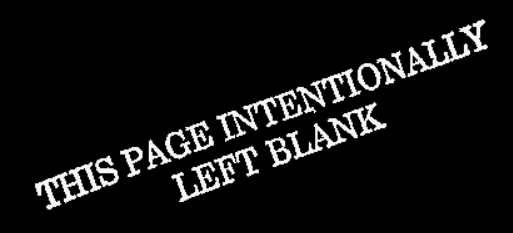




\section{RELEASE AUTHORIZATION}

\begin{tabular}{|ll|}
\hline Document Number: & WHC-SD-WM-ER-507, REV 0 \\
\hline Document Title: & $\begin{array}{l}\text { Tank 241-S-111 Headspace Gas and Vapor } \\
\text { Characterizat ion Results for Samples Collected in } \\
\text { March 1995 }\end{array}$ \\
\hline Release Date: & $9 / 26 / 95$ \\
\hline & This document was reviewed following the \\
procedures described in WHC-CM-3-4 and is: & \\
& APPROVED FOR PUBLIC RELEASE \\
WHC Information Release Administration Specialist: \\
Kara Broz
\end{tabular}

TRADEMARK DISCLAIMER. Reference herein to any specific commercial product, process, or service by trade name, trademark, manufacturer, or otherwise, does not necessarily constitute or imply its endorsement, recommendation, or favoring by the United States Government or any agency thereof or its contractors or subcontractors.

This report has been reproduced from the best available copy. Available in paper copy. Printed in the United States of America. To obtain copies of this report, contact:

Westinghouse Hanford Company - Document Control Services

P.0. Box 1970, Mailstop H6-08, Richland, WA 99352

Telephone: (509) 372-2420; Fax: (509) 376-4989 


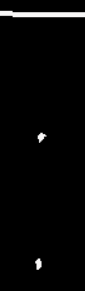


2. Title

TANK 241-S-111 HEADSPACE GAS AND VAPOR CHARACTERIZATION RESULTS FOR SAMPLES COLLECTED IN MARCH 1995

\section{Key Words}

CHARACTERIZATION OBJECTIVES, TANK HEADSPACE, SAMPLING EVENT, INORGANIC GASES, ORGANIC VAPORS
3. Number

WHC-SD-WM-ER-507
4. Rev No.

0
6. Author

Name:

D. R. BRATZEL

Signature

Organization/Charge code $75640 / N 4 A B I$

\section{Abstract}

Significant changes have been made to all of the original vapor characterization reports. This report documents specific headspace gas and vapor characterization results for all vapor sampling events to date. In addition, changes have been made to the original vapor reports to qualify the data based on qual ity assurance issues associated with the performing laboratories. 



\title{
Tank 241-S-111 Headspace Gas and Vapor Characterization Results for Samples Collected in March 1995
}

\author{
J. L. Huckaby
}

Pacific Northwest Laboratories

D. R. Bratzel

Westinghouse Hanford Company

Date Published

September 1995

Prepared for the U.S. Department of Energy

Office of Environmental Restoration and

Waste Management

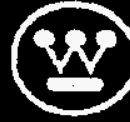

Westinghouse

P.O Box 1970

Hanford Company Richland, Washington

Management and Operations Contractor for the

U.S. Department of Energy under Contrect DE.AC06-87FL10930

Approved for Public Release 


\section{Contents}

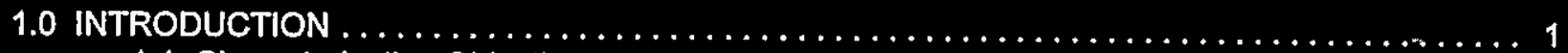

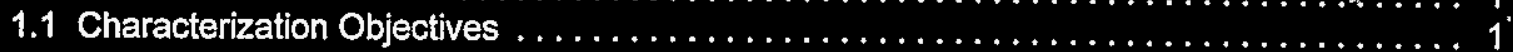

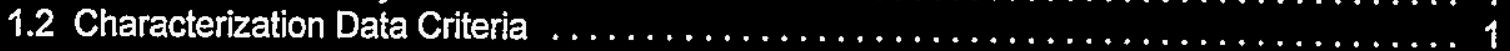

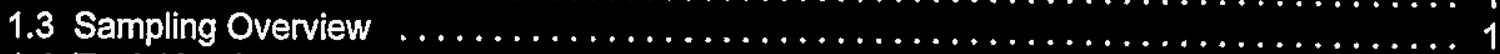

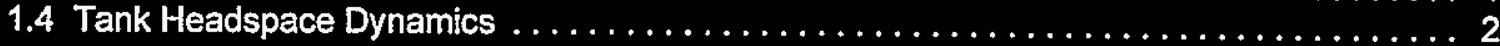

2.0 SAMPLING EVENT $\ldots \ldots \ldots \ldots \ldots \ldots \ldots \ldots \ldots \ldots \ldots \ldots \ldots \ldots \ldots \ldots \ldots \ldots$

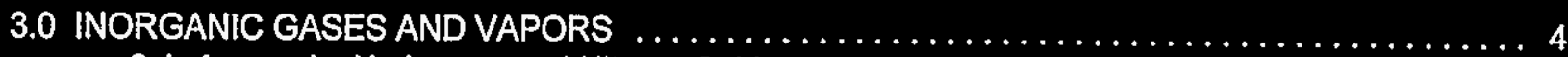

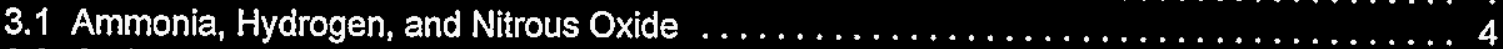

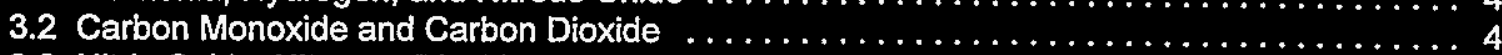

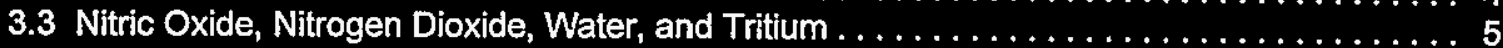

3.4 Discussion of Inorganic Gases and Vapors $\ldots \ldots \ldots \ldots \ldots \ldots \ldots \ldots \ldots \ldots \ldots$

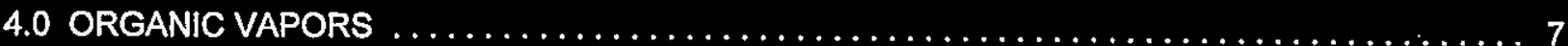

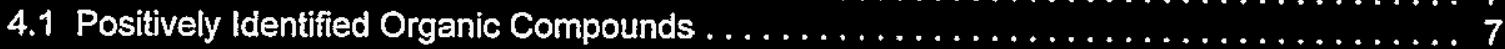

4.2 Tentatively Identified Organic Compounds $\ldots \ldots \ldots \ldots \ldots \ldots \ldots \ldots \ldots \ldots$

4.3 Discussion of Organic Compounds $\ldots \ldots \ldots \ldots \ldots \ldots \ldots \ldots \ldots \ldots \ldots \ldots$

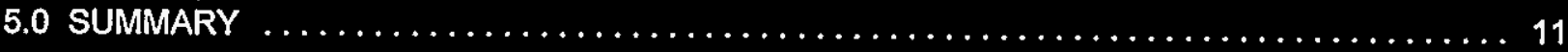

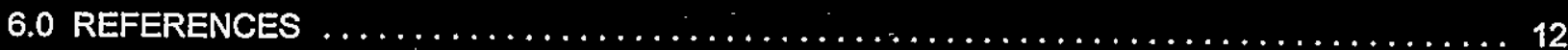

\section{Acronyms and Abbreviations}

$\begin{array}{ll}\text { CES } & \text { consensus exposure standard } \\ \text { EPA } & \text { Environmental Protection Agency } \\ \text { GC } & \text { gas chromatograph } \\ \text { GC/MS } & \text { gas chromatograph/mass spectrometer } \\ \text { LFL } & \text { lower flammability limit } \\ \text { MS } & \text { mass spectrometer } \\ \text { NFPA } & \text { National Fire Protection Association } \\ \text { NPH } & \text { normal parafinic hydrocarbon } \\ \text { ORNL } & \text { Oak Ridge National Laboratory } \\ \text { PNL } & \text { Pacific Northwest Laboratory } \\ \text { ppmv } & \text { parts per million by volume, } 1 \text { ppmv }=10^{-4} \text { vol\% } \\ \text { TST } & \text { triple sorbent trap } \\ \text { vol\% } & \text { percent by volume, 1 vol\% }=10,000 \text { ppmv } \\ \text { VSS } & \text { vapor sampling system } \\ \text { WHC } & \text { Westinghouse Hanford Company }\end{array}$

Acknowledgements

The authors wish to thank Chris Simonen for her work verifying data and generating tables, and Shas Mattigod for his help with the construction and reviews of this document. The authors also wish to thank Luther Buckley, Clarence Homi, and Tom Kunthara for their contributions to the final reviews and publication of this document. 


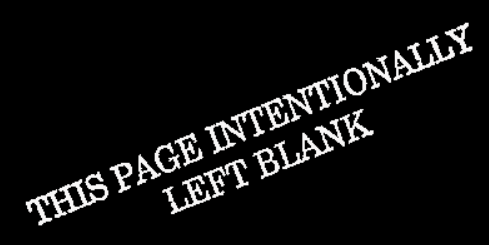


Tank 241-S-111 Headspace Gas and Vapor Characterization Results

\author{
for Samples Collected in March 1995
}

\title{
1.0 INTRODUCTION
}

\subsection{Characterization Objectives}

Tank S-111 headspace gas and vapor samples were collected and analyzed to help determine the potential risks of fugitive emissions to tank farm workers. The drivers and objectives of waste tank headspace sampling and analysis are discussed in Program Plan for the Resolution of Tank Vapor Issues (Osborne and Huckaby 1994). Tank S-111 was vapor sampled in accordance with Data Quality Objectives for Generic In-Tank Health and Safety Issue Resolution (Osborne et al. 1994).

\subsection{Characterization Data Criteria}

Data Quality Objectives for Generic In-Tank Health and Safety Issue Resolution describes parameters for data collection to ensure appropriate conclusions can be drawn from the data. Tank headspace characterization data was collected to help in the evaluation of 1) headspace flammability, and 2) identification and quantification of compounds of toxicological concern.

Single Shell Tank Interim Operational Safety Requirements (Dougherty 1995) specifies that combustible constituents in tank headspaces be maintained below $25 \%$ of the lower flammability limit (LFL). This essentially agrees with National Fire Protection Association requirements that combustible concentrations be maintained at or below $25 \%$ of the LFL (NFPA 1992). However, current governing operating specifications for single shell Watchlist waste tanks, such as tank S-111, specify that combustible constituents be maintained at or below $20 \%$ of the LFL (WHC 1995a).

Headspace characterization data are used by Westinghouse Hanford Company (WHC) Tank Waste Remediation Systems Industrial Hygiene as source term data in the industrial hygiene strategy to protect workers from tank fugitive emissions. Because selection of worker protective equipment must be based on industrial hygiene monitoring of the work place and not on source term data (29 CFR 1910.120), tank headspace characterization data can not be used for this purpose. Furthermore, because there are mechanisms by which headspace constituents can be either diluted or concentrated as they are released to the atmosphere, the headspace characterization data should not be considered to be representative of emissions at the point of emission.

These statements notwithstanding, the data quality objectives document specifies that the industrial hygiene group be advised if constituents with toxicological properties exceed $50 \%$ of the appropriate consensus exposure standard (CES) for non-carcinogens, or $10 \%$ of the appropriate CES for carcinogens. A CES is defined as the most stringent of known regulatory or recommended toxicological values for the workplace (Osborne et al. 1994).

\subsection{Sampling Overview}


Tank headspace characterization data presented here are from a single sampling event. Samples collected are thought to have been representative of the tank S-111 headspace when the tank was sampled, and sample analyses were designed to provide a reasonably accurate and complete characterization of the significant headspace constituents (Meacham et al. 1995). No assessment has been made of how the tank S-111 headspace composition changes with time, though studies of tank C103 suggest that composition changes probably occur very slowly in the passively ventilated tanks (Huckaby and Story 1994).

\subsection{Tank Headspace Dynamics}

Tank S-111 is the second tank in a 3-tank cascade with tanks S-110 and S-112. It is connected to tanks S-110 and S-112 via a 7.4-cm (2.9-in.) inside diameter, 7.6-m (25-ft) long underground cascade lines. Since these cascade lines connect the headspaces of these tanks, gases and vapors originating from the wastes in tank S-110 of tank S-112 may be transferred to tank S-111 (unless the cascade lines are obstructed). At this time, however, no headspace characterization data is available for either tanks $\$-110$ or S-112 to assess their potential effect on tank S-111.

The cascade of tanks S-110, S-111, and S-112 is passively ventilated, which means that the tanks are allowed to exhale air, waste gases, and vapors as the barometric pressure falls, and inhale ambient air as the barometric pressure rises. Each of these tanks has its own filtered breather riser. Barometric pressure typically rises and falls on a diurnal cycle, producing an average daily exchange of air equal to about $0.46 \%$ of each tank headspace (Huckaby 1994). Changes in the concentrations of tank headspace constituents due to barometric pressure changes are consequently very slow. 


\subsection{SAMPLING EVENT}

Headspace gas and vapor samples were collected from tank S-111 using the vapor sampling system (VSS) on March 21, 1995 by WHC Sampling and Mobile Laboratories (WHC 1995b). Sample collection and analysis were performed as directed by Tank 241-S-111 Tank Characterization Plan (Homi 1995a). The tank headspace temperature was determined to be $23^{\circ} \mathrm{C}$. Air from the S-111 headspace was withdrawn from a single elevation via a 6.7- $\mathrm{m}$ long heated sampling probe mounted in riser 14 , and transferred via heated tubing to the VSS sampling manifold. All heated zones of the VSS were maintained at approximately $60^{\circ} \mathrm{C}$. All tank air samples were collected between 11:12 a.m. and 3:17 p.m., with no anomalies noted.

Sampling media were prepared and analyzed by WHC, Oak Ridge National Laboratories (ORNL), and Pacific Northwest Laboratories (PNL). The 40 tank air samples and 2 ambient air control samples collected are listed in Table 2-1 by analytical laboratory. Table 2-1 also lists the 14 trip blanks and 2 field blanks provided by the laboratories.

A general description of vapor sampling and sample analysis methods is given by Huckaby et al. (1995). The sampling equipment, sample collection sequence, sorbent trap sample air flow rates and flow times, chain of custody information, and a discussion of the sampling event itself are given in WHC (1995b). 


\subsection{INORGANIC GASES AND VAPORS}

Analytical results of sorbent trap and SUMMA ${ }^{T M}, 1$ canister tank air samples for selected inorganic gases and vapors are given in Table 2-1 in parts per million by volume (ppmv) in dry air. The concentration of water vapor given in Table 3-1 has been adjusted to tank conditions as given in Section 3.3. All inorganic gas and vapor tank samples, ambient air samples, and trip and field blanks were prepared and analyzed by PNL per PNL quality assurance impact level 2 procedures (Klinger et al. 1995a). PNL analyses of SUMMA ${ }^{\mathrm{TM}}$ canisters and sorbent traps for inorganic compounds were performed 51 and 20 days, respectively, after sample collection (Ligotke 1995). Both SUMMA ${ }^{\mathrm{TM}}$ canister, and sorbent trap analyses were within the maximum 60-day holding time allowed by the WHC quality assurance project plan (Keller 1994).

\subsection{Ammonia, Hydrogen, and Nitrous Oxide}

Six sorbent trap samples from tank S-111 indicated an average ammonia concentration of $122 \mathrm{ppmv}$. This concentration of ammonia is typical of the waste tanks that have been sampled. Ammonia has been observed in virtually all of the passively ventilated waste tanks sampled to date, at concentrations ranging from about 3 ppmv in tank C-108 (Lucke et al. 1995), to 1040 ppmv in BY-108 (MoVeety et al. 1995). Given the LFL of ammonia in air is about $15 \%$ by volume (vol\%), the measured 122 ppmv corresponds to about $0.08 \%$ of the LFL, and does not contribute appreciably to the flammability of the headspace.

The concentration of hydrogen in tank S-111 was determined to be 391 ppmv. Hydrogen in the waste tanks is of concern as a fuel. Given that the LFL for hydrogen in air is about 4 vol\%, 391 ppmv hydrogen concentration in tank S-111 corresponds to about $1 \%$ of its LFL. At this level, hydrogen is not a flammability concern in tank S-111.

The average nitrous oxide concentration reported by PNL for the 3 SUMMA ${ }^{\mathrm{TM}}$ canister samples was 48 ppmv. Nitrous oxide has been detected in other passively ventilated waste tanks at average concentrations as low as about 12 ppmv in tank TX-105 (Klinger et al. 1995b), and as high as 878 ppmv in tank U-103 (Ligotke et al. 1995). Under the proper conditions, nitrous oxide can serve as an oxidizer to support combustion. However, Cashdollar et al. (1992) found that nitrous oxide had no significant effect on the flammability of hydrogen and air mixtures for hydrogen concentrations less than $20 \mathrm{vol} \%$, and that "small amounts of nitrous oxide (relative to air) do not appear to have much effect on the flammability". Their results suggest the measured nitrous oxide concentration is much too low to have a significant effect on the flammability of the tank S-111 headspace.

\subsection{Carbon Monoxide and Carbon Dioxide}

Carbon monoxide in the tank S-111 headspace was measured to be $<23$ ppmv in all 3 SUMMA ${ }^{\text {TM }}$ canister samples. In ambient air it typically ranges from 0.05 to $0.15 \mathrm{ppmv}$. Because different analytical methods have been used to measure carbon monoxide in the waste tanks sampled to date, the information on carbon monoxide has varied from tank to tank. However, in waste tank headspace elevated carbon monoxide concentrations are common, and are thought to be due to the decomposition of organic waste

1 SUMMA is a trademark of Molectrics, Inc., Cleveland, Ohio. 
in the tanks. Carbon monoxide has not been measured at very high levels in any of the waste tanks, the highest level measured to date was [26.7 ppmv] in tank C-103² (Huckaby and Story 1994).

The carbon dioxide concentration in the tank S-111 headspace, reported to be $<23$ ppmv in all 3 of the SUMMA ${ }^{\mathrm{TM}}$ canister samples, is significantly lower than it is in ambient air. Carbon dioxide is normally present in the ambient air at a concentration of 350 to 400 ppmv, and is typically lower than ambient in the waste tank headspaces. The 2 ambient air samples collected at the start of the tank S-111 gas and vapor sampling event, for example, were measured to have an average 354 ppmv of carbon dioxide.

Carbon dioxide introduced by air exchange with the atmosphere is readily absorbed by caustic supernatant and interstitial liquids in the waste tanks, and converted to carbonate in solution. Like the carbon monoxide measurements, because different analytical methods have been used to measure carbon dioxide in the waste tank samples, the information on waste tank carbon dioxide varies. The $<23$ ppmv of carbon dioxide characterization of the tank S-111 headspace is consistent with typical values for the waste tanks that have been sampled.

\subsection{Nitric Oxide, Nitrogen Dioxide, Water, and Tritium}

Nitric oxide and nitrogen dioxide concentrations in the tank S-111 headspace were determined to be $\leq$ 0.07 and $\leq 0.01 \mathrm{ppmv}$, respectively. These are acid gases that would have very low equilibrium concentrations above the high pH sludge in tank S-111. The measurable presence of nitric oxide is not uncommon in the waste tank headspaces, and may be due to its formation from oxygen and nitrogen in the radiation field of the headspace. These constituents could potentially serve as oxidizers to support combustion, but at the measured concentrations would have a negligible effect on the flammability of the tank S-111 headspace.

The water vapor concentration of tank S-111 was determined to be about $11.0 \mathrm{mg} / \mathrm{L}$, at the measured tank headspace temperature of $23^{\circ} \mathrm{C}$ and pressure of $975 \mathrm{mbar}$ (731.2 torr), (WHC 1995b). This corresponds to a water vapor partial pressure of $15.0 \mathrm{mbar}\left(11.2\right.$ torr), to a dew point of $13^{\circ} \mathrm{C}$, and to a relative humidity of about $53 \%$.

Silica gel sorbent traps were used to test for tritium. It is assumed that tritium produced by the waste combines with hydroxide ions to form tritium-substituted water. Evaporation of the tritium-substituted water would then result in airborne radioactive contamination. Silica gel sorbent traps adsorb virtually all (normal and tritium-substituted) water vapor from the sampled tank air, and are analyzed at the WHC 222S laboratory. Radiochemical analysis of the silica gel trap indicated the total activity of the headspace to be less than 50 pCill. (WHC 1995b).

\subsection{Discussion of Inorganic Gases and Vapors}

Except for water vapor, the most abundant waste constituents in the tank S-111 headspace are hydrogen, ammonia, and nitrous oxide. These have been detected in most of the tank headspaces that have been sampled, and are usually the dominant gaseous species.

2 The carbon monoxide measurement in tank C-103 was made by Oregon Graduate Institute of Science and Technology, and placed in brackets to emphasize it should be considered secondary data. 
WHC-SD-WM-ER-507 REV. 0

The relative standard deviations of the inorganic gas and vapor results given in the last column in Table 21 are good for the methods used. Relative standard deviations range from about $0.3 \%$ for hydrogen to about $4 \%$ for nitrous oxide. Because the precision reported depends both on sampling parameters (e.g., sample flow rate and flow time for sorbent traps) and analytical parameters (e.g., sample preparation, dilutions, etc.), small relative standard deviations suggest proper control was maintained both in the field and in the laboratories. 


\subsection{ORGANIC VAPORS}

Organic vapors in the tank S-111 headspace were sampled using SUMMATM canisters, which were analyzed by PNL, and triple sorbent traps (TSTs), which were analyzed by ORNL. Both PNL and ORNL. used a gas chromatograph (CC) equipped with a mass spectrometer (MS) detector to separate, identify, and quantitate the analytes. Descriptions of sample device cleaning, sample preparations, and analyses are given by Jenkins et al. (1995a) and Klinger et al. (1995a).

SUMMA ${ }^{\mathrm{TM}}$ sample results should be considered to be the primary organic vapor data for tank $\mathrm{S}-111$. PNL results were produced at PNL quality assurance impact level 2. All PNL analyses were completed 55 days after sample collection (Ligotke 1995), which was within the administratively chosen 60-day maximum holding time (Keller 1994). No holding time study has been performed to determine the stability of organic analytes in SUMMA ${ }^{\mathrm{TM}}$ canisters in the chemical matrix of the tank samples.

ORNL analyses of TST samples from this and other waste tanks generally agree with, support, and augment the SUMMA ${ }^{\mathrm{TM}}$ sample results. However, because certain WHC quality assurance requirements were not satisfied by ORNL, the quality assurance assessment of ORNL by Hendrickson (1995) should be reviewed before results unique to the TST samples are used for decision making.

All TSTs prepared by ORNL had 3 surrogate compounds added to evaluate sample matrix effects, potential handling, storage, and shipment problems, and analytical instrumentation performance (Jenkins et al. 1995a). ORNL evaluated the surrogate recoveries using a statistical approach similar to that prescribed by SW 846 Method 8260 A Volatile Organic Compounds by Gas Chromatography/Mass Spectrometry (GCMS) Capillary Column Technique (EPA 1992). Using this approach, ORNL reported that all surrogates had standard deviation values within the $95 \%$ confidence interval for variance, indicating that no bias was introduced in the measurement of analyte quantities (Jenkins 1995a).

\subsection{Positively Identified Organic Compounds}

Positive identification of organic analytes using the methods employed by PNL and ORNL involves matching the GC retention times and MS data from a sample with that obtained from the analysis of standards. The concentration of an analyte in the sample is said to be quantitatively measured if the response of the GC/MS has been established at several known concentrations of that analyte (i.e., the GC/MS has been calibrated for that analyte), and the MS response to the analyte in the sample is between the lowest and highest responses to the known concentrations (i.e., the analyte is within the calibration range).

ORNL and PNL. were assigned different lists of organic compounds, or target analytes, to positively identify and measure quantitatively. The ORNL target analyte list was derived from a review of the tank C103 headspace constituents by a panel of toxicology experts (Mahlum et al. 1994). The PNL target analyte list included 39 compounds in the Environmental Protection Agency (EPA) task order 14 (TO-14) method, which are primarily halocarbons and common industrial solvents (EPA 1988), plus 14 analytes selected mainly from the toxicology panel's review of vapor data from tank C-103.

Table 4-1 lists the organic compounds positively identified and quantitated in SUMMATM samples. SUMMA ${ }^{\mathrm{TM}}$ analyses were performed according to a modified version of the TO-14 methodology, except for methane analysis, which was analyzed with the inorganic gases (Klinger et al. 1995a). Only 2 of the 39 TO-14 target analytes and 5 of the 14 additional target analytes were measured to be above the 0.005 
ppmv detection limit of the analyses. Averages reported are from analyses of 3 SUMMA ${ }^{\text {TM }}$ canister samples.

Jenkins et al. (1995a) report the positive identification of 25 of 27 target analytes in TST samples. Dibutyl butylphosphonate and tributyl phosphate were the only TST target analytes not detected, though dichloromethane was detected in only 1 TST sample. The average concentrations of the two detected and quantitated detected target analytes (ethanenitrile, and toluene), from the analysis of 4 TSTs, are given in Table 4-2. Despite calibration of the instrument over about a 20-fold concentration range, the concentrations of 18 compounds were determined to be below the lower callbration limit of the analyses in at least 1 of the TST samples. These analytes are listed in Table 4-3. Data in Table 4-3 should not be considered quantitative and may not be accurate to within $\pm 30 \%$ as specified by Burnum (1995).

The ORNL practical holding time is defined as the holding time for which there is a $15 \%$ risk that the concentration of an analyte in the sample will be below its initial concentration. Table 4-4 lists the 5 analytes which exceeded the ORNL practical holding times, and may have been affected by the 51-day period between sample collection and analysis (Jenkins 1995b). Jenkins et al. (1995b) describe the ORNL practical holding time study, and report practical holding times for these compounds. It should be noted that the contractual holding time for the TST samples was 60 days. Data in Table $4-4$ may not be accurate to within $\pm 30 \%$ as specified by Burnum (1995).

Eleven target analytes were common to both TST and SUMMA TM analyses. Table 4-5 lists these, and their reported average concentrations in TST and SUMMATM samples. Eight of these 11 analytes were determined by both laboratories to be below the 0.005 ppmv PNL analytical detection limit, and resuits for the remaining 3 analytes agree reasonably well.

Both PNL and ORNL report target analyte concentrations in ppmv of analyte in dry air. To correct for the measured water vapor content of tank S-111 and obtain concentration in ppmv of analyte in mojst tank air, multiply the dry-air ppmv concentrations by 0.985 .

The most abundant analytes in Tables 4-1 through 4-4 are propanone and 1-butanol, both of which was measured to have an average concentration of between 0.05 and 0.2 ppmv in the tank S-111 samples. At the reported concentrations, the target analytes do not individually or collectively represent a flammability hazard.

\subsection{Tentatively Identified Organic Compounds}

In addition to the target analytes, the ORNL and PNL analytical procedures allow the tentative identification of other organic compounds: Tentative identification of analytes was performed by comparing the MS molecular fragmentation patterns with a library of known MS fragmentation patterns. This method allows an organic analyte to be identified (with reasonable certainty) as an alkane, a ketone, an aldehyde, etc., and may also determine its molecular weight. The method usually does not, however, allow the unambiguous identitication of structural isomers, and this ambiguity increases with analyte molecular weight. Using these methods, many analytes can be tentatively identified with reasonable confidence without having to inject standards of each into the GC/MS to determine their GC retention times or specific MS patterns.

By the nature of the sampling devices, virtually all organic vapors present in the tank headspace are collected by both TST and SUMMA ${ }^{\mathrm{TM}}$ samples. Analyses of the samples are designed to recover, separate, and identify the organic vapors in the samples. TSTs are not good for collecting highly volatile 
compounds (i.e., molecules more volatile than propane), but are quite good for most others. In contrast, the recovery of very low volatility compounds (e.g., molecules with more than about 15 carbon atoms) and some polar compounds with moderate volatility (e.g., butanal) from SUMMA ${ }^{\mathrm{TM}}$ samples has been problematic.

The list of tentatively identified compounds recovered from SUMMA ${ }^{\mathrm{TM}}$ samples, with estimated concentrations, is given in Table 4-6. Compounds are listed in Table 4-6 in order of decreasing estimated concentration, and only non-zero results are included in the reported averages. The list of tentatively identified compounds detected in TST samples, and their estimated concentrations, is given in Table 4-7. Compounds are listed in Table 4-7 in the order by which they eluted chromatographically. The averages reported by ORNL in Table 4-7 are all 4-sample averages, and if an analyte was not detected in a sample, its concentration in that sample was considered to be zero for averaging purposes. Estimated concentrations are in $\mathrm{mg} / \mathrm{m}^{3}$, based on dry air at $0^{\circ} \mathrm{C}$ and 1.01 bar.

Because the list of tentatively identified organic compounds in TST samples is rather long and locating any given compound may be difficult, this list has been sorted alphanumerically by compound name in Table 4-8, and also in order of decreasing estimated concentrations in Table 4-9. Numbers in the first columns of Tables 4-8 and 4-9 (Cmpd \#) identify the location of the compound in Table 4-7.

The ORNL and PNL methods used to tentatively identify and estimate concentrations are described by Jenkins et al. (1995a) and Klinger et al. (1995a), respectively, and should be reviewed before this data is used for decision making. Concentrations given in Tables 4-6 through 4-9 should be considered rough estimates.

\subsection{Discussion of Organic Compounds}

A convenient way to consider the organic compounds listed in Tables 4-1 through 4-7 is to separate them into 2 categories: 1) Organic compounds added to tank S-111 as waste that are still evaporating; and 2) organic compounds that have been generated by reactions of the original waste.

The first category encompasses all organic compounds that were placed into the tank as waste. This category includes the semivolatile straight-chain alkanes, which were used as diluents of tributyl phosphate in various plutonium extraction processes. These alkanes (i.e., n-undecane, n-dodecane, ntridecane, and n-tetradecane) are often referred to in Hanford site literature as the normal paraffinic hydrocarbons (NPHs). Though NPHs are positively identified in tank S-111, their concentrations are very low compared to other NPH-rich tanks.

Tributyl phosphate was probably also added to the tank as waste. The fact that tributyl phosphate was not detected in the tank S-111 samples does not preclude its existence in either the waste or the headspace of tank S-111. Informal tests by ORNL indicate that tributyl phosphate is adsorbed by the glass fiber filters used during sampling to protect the samples from radiolytic particulate contamination. This would result in loss of tributyl phosphate from the sampled air, and an underestimation of its actual concentration in the tank headspace. The prominence of 1-butanol, a known hydrolysis product of tributyl phosphate, in the tank S-111 organic vapor samples suggests that small amounts of tributyl phosphate are present in the waste.

The second category includes all organic compounds that have been generated via radiolytic and chemical reactions of the waste. The majority of compounds listed in Tables 4-1 through 4-7 fall into this category, including the alcohols, aldehydes, ketones, nitriles, and volatile alkanes, all of which have been 
associated with the degradation of the NPHs. Though not present in high concentrations, 6 straight-chain alkyl nitriles were identified in TST samples. Several nitrogen heterocyclic compounds were also detected in TST samples.

On the basis of concentrations, alcohols are the dominant organic compounds in the tank $\$-111$ headspace. Methanol, ethanol, and 1-propanol account for about $20 \%$ of the total estimated concentration of organic compounds in TST samples, and about $46 \%$ of the total estimated concentration of organic compounds in SUMMA ${ }^{\mathrm{TM}}$ canister samples. The abundance of volatile alcohols is common to most other waste tanks located in the 200 West area of the Hanford Site.

The total organic vapor concentration of tank S-111 was estimated by Jenkins et al. (1995a) to be about $1.5 \mathrm{mg} / \mathrm{m}^{3}$ from the analysis of 4 TST samples by GC/MS. A similar summation of organic compounds measured in SUMMA ${ }^{\mathrm{TM}}$ samples from tank S-111 provides an estimated total organic vapor concentration of $2.0 \mathrm{mg} / \mathrm{m}^{3}$. This disagreement is largely due to the different estimated concentrations of the dominant alcohols in the 2 sample types.

In summary, the organic vapor concentrations in tank S-111 are relatively low. The organic vapors in tank S-111 indicate that small quantities of the NPH process diluent and tributyl phosphate may be present in the waste. As with most other 200 West Area waste tanks that have been sampled, the concentrations of short-chain alcohols are higher in tank S-111 than in waste tanks with higher NPH vapor concentrations. Conversely, ketories and aldehydes are less abundant in tank S-111 than in NPH-rich waste tanks. 
WHC-SD-WM-ER-507 REV. 0

\subsection{SUMMARY}

The tank S-111 headspace was sampled in March 1995 for gases and vapors to address flammability and industrial hygiene concerns. Collection and analysis of samples has been reported. It was determined that no headspace constituents exceeded the flammability or indrustrial hygiene notification limits specified in the current Vapor Sampling and Analysis Plan (Homi 1995b). 


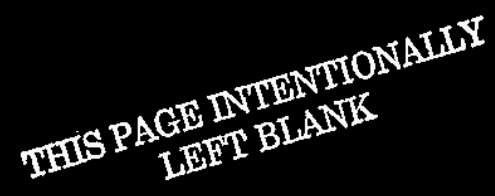


WHC-SD-WM-ER-507 REV. 0

\subsection{REFERENCES}

29 CFR 1910.120, 1993, "Hazardous Waste Operations and Emergency Response", Code of Federal Regulations.

Burnum, S. T., 1995, Qualification of Reported WHC Vapor Program Data, (letter 95-CHD-065 to president, Westinghouse Hanford Company, August 18), Department of Energy, Richland Operations Office, Richland, Washington.

Cashdollar, K. L., M. Hertzberg, I. A. Zlochower, C. E. Lucci, G. M. Green, and R. A. Thomas, 1992, Laboratory Flammability Studies of Mixtures of Hydrogen, Nitrous Oxide, and Air, WHC-SD-WMES-219 Rev. 0, Westinghouse Hanford Company, Richland, Washington.

Dougherty, L. F., 1995, Single Shell Tank Interim Operational Safety Requirements, WHC-SD-WM-OSR005 Rev. 0, Westinghouse Hanford Company, Richland, Washington.

EPA 1988, Compendium of Methods for the Determination of Toxic Organic Compounds in Ambient Air, PB90-127374, U.S. Environmental Protection Agency, Washington, D.C.

EPA 1992, Test Methods for Evaluating Solid Waste, SW-846 Rev. 1, U.S. Environmental Protection Agency, Washington, D.C.

Hendrickson, R. W., 1995, Tank Vapor Characterization Oak Ridge National Laboratories Quality Assurance Assessment, TWRSQA-95-0012, Westinghouse Hanford Company, Richland, Washington.

Homi, C. S., 1995a, Tank 241-S-111 Tank Characterization Plan, WHC-SD-WM-TP-317, Westinghouse Hanford Company, Richland, Washington.

Homi, C. S., 1995b, Vapor Sampling and Analysis Plan, WHC-SD-WM-TP-335 Rev. 0G, Westinghouse Hanford Company, Richland, Washington.

Huckaby, J. L., 1994, Tank 241-C-103 Headspace Flammability, WHC-EP-0734 Rev. 1, Westinghouse Hanford Company, Richland, Washington.

Huckaby, J. L., H. Babad, and D. R. Bratzel, 1995, Headspace Gas and Vapor Characterization Summary for the 43 Vapor Program Suspect Tanks, WHC-SD-WM-ER-514 Rev. 0, Westinghouse Hanford Company, Richland, Washington.

Huckaby, J. L., and M. S. Story, 1994, Vapor Characterization of Tank 241-C-103, WHC-EP-0780 Rev. 0, Westinghouse Hanford Company, Richland, Washington.

Jenkins, R. A., 1995a, Untitled, (Letter 090195A to D. Bratzel, September 1), Oak Ridge National Laboratory, Oak Ridge, Tennessee.

Jenkins, R. A., 1995b, Untitled, (Letter 091495A to D. Bratzel, September 14), Oak Ridge National Laboratory, Oak Ridge, Tennessee. 
Jenkins, R. A, A. B. Dindal, C. Y. Ma, M. A. Palausky, J. T. Skeen, and C. K. Bayne, 1995a, Analysis of Tank 241-S-111 Headspace Components, ORNL-CASD-FR-241S111.95 Rev. 0, Oak Ridge National Laboratory, Oak Ridge, Tennessee.

Jenkins, R. A, A. B. Dindal, C. Y. Ma, M. A. Palausky, J. T. Skeen, and C. K. Bayne, 1995b, Analysis of Tank 241-TY-104 Headspace Components, ORNL-CASD-FR-241TY104.95 Rev. 1, Oak Ridge National Laboratory, Oak Ridge, Tennessee.

Ligotke, M. W. 1995, PNL Vapor Project Analytical Holding Times, (Letter to D.R. Bratzel, September 23, 1995), Pacific Northwest Laboratory, Richland, Washington.

Ligotke, M. W., K. H. Pool, T. W. Clauss, B. D. McVeety, G. S. Klinger, K. B. Olsen, O. P. Bredt, J. S. Fruchter, and S. C. Goheen, 1995, Vapor Space Characterization of Waste Tank 241-U-103: Results from Samples Collected on 2/15/95, PNL-10813 UC-606, Pacific Northwest Laboratory, Richland, Washington.

Keller, K. K., 1994, Quality Assurance Project Plan for Tank Vapor Characterization, WHC-SD-SM-QAPP. 013 Rev.2, Westinghouse Hanford Company, Richland, Washington.

Klinger, G. S., T. W. Clauss, M. W. Ligotke, K. H. Pool, B. D. MoVeęty, K. B. Olsen, O. P. Bredt, J. S. Fruchter, and S. C. Goheen, 1995a, Vapor Space Characterization of Waste Tank 241-S-111: Results from Samples Collected on 3/21/95, PNL-10733 UC-606, Pacific Northwest Laboratory, Richland, Washington.

Klinger, G. S., T. W. Clauss, M. W. Ligotke, K. H. Pool, R. B. Lucke, B. D. McVeety, O. P. Bredi, J. S. Young, M. McCulloch, J. S. Fruchter, and S. C. Goheen, 1995b, Vapor Space Characterization of Waste Tank 241-TX-105: Results from Samples Collected Through the Vapor Sampling System on 12/20/94, PNL-10594 UC-606, Pacific Northwest Laboratory, Richland, Washington.

Lucke, R. B., M. W. Ligotke, K. H. Pool, T. W. Clauss, A. K. Sharma, B. D. McVeety, M. McCulloch, J. S. Fruchter, and S. C. Goheen, 1995, Vapor Space Characterization of Waste Tank 241-C-108: Results from Samples Collected Through the Vapor Sampling System on 8/5/94, PNL-10351 UC606, Pacific Northwest Laboratory, Richland, Washington.

Mahlum, D. D., J. Y. Young, and R. E. Weller, 1994, Toxicologic Evaluation of Analytes from Tank 231-C103, PNL-10189, Pacific Northwest Laboratory, Richland, Washington.

McVeety, B. D., T. W. Clauss, M. W. Ligotke, K. H. Pool, R. B. Lucke, G. S. Klinger, J. S. Young, M. McCulloch, J. S. Fruchter, and S. C. Goheen, 1995, Vapor Space Characterization of Waste Tank 241-BY-108: Results from Samples Collected on 10/27/94, PNL-10495 UC-606, Pacific Northwest Laboratory, Richland, Washington.

Meacham, J. E., H. Babad, R. J. Cash, G. T. Dukelow, S. J. Eberiein, D. W. Hamilton, G. D. Johnson, J. W. Osborne, M. A. Payne, D. J. Sherwood, D. A. Turner, and J. L. Huckaby, 1995, Approach for Tank Safety Characterization of Hanford Site Waste, WHC-EP-0843, Westinghouse Hanford Company, Richland, Washington.

NFPA 1992, Standard on Explosion Prevention Systems, NFPA 69, National Fire Protection Association, Quincy, Massachusetts. 
Osborne, J. W., and J. L. Huckaby, 1994, Program Plan for the Resolution of Tank Vapor /ssues, WHCEP-0562 Rev. 1, Westinghouse Hanford Company, Richland, Washington.

Osborne, J. W., J. L. Huckaby, T. P. Rudolph, E. R. Hewitt, D. D. Mahlum, J. Y. Young, and C. M. Anderson, 1994, Data Quality Objectives for Generic In-Tank Health and Safety Issue Resolution, WHC-SD-WM-DQO-002, Westinghouse Hanford Company, Richland, Washington.

WHC 1995a, Operating Specifications for Watchlist Tanks, OSD-T-151-00030, Rev. B-9, Westinghouse Hanford Company, Richland, Washington.

WHC 1995b, Vapor and Gas Sampling of Single-Shell Tank 241-S-111 Using the Vapor Sampling System, WHC-SD-WM-RPT-143, Westinghouse Hanford Company, Richland, Washington. 


$$
\begin{aligned}
& \text { TITS PAGE INTENTIONAIII } \\
& \text { IIET BLANT }
\end{aligned}
$$




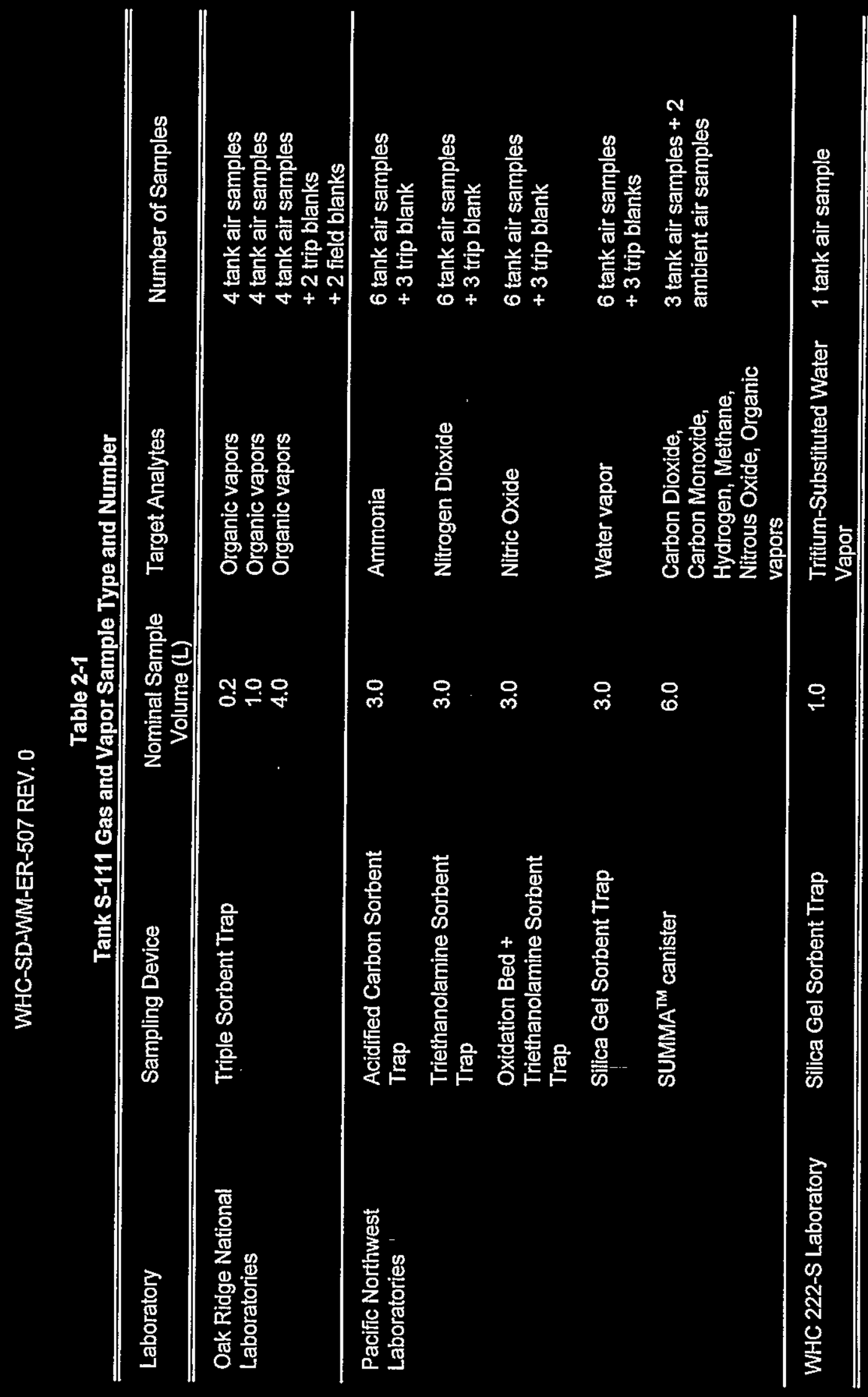




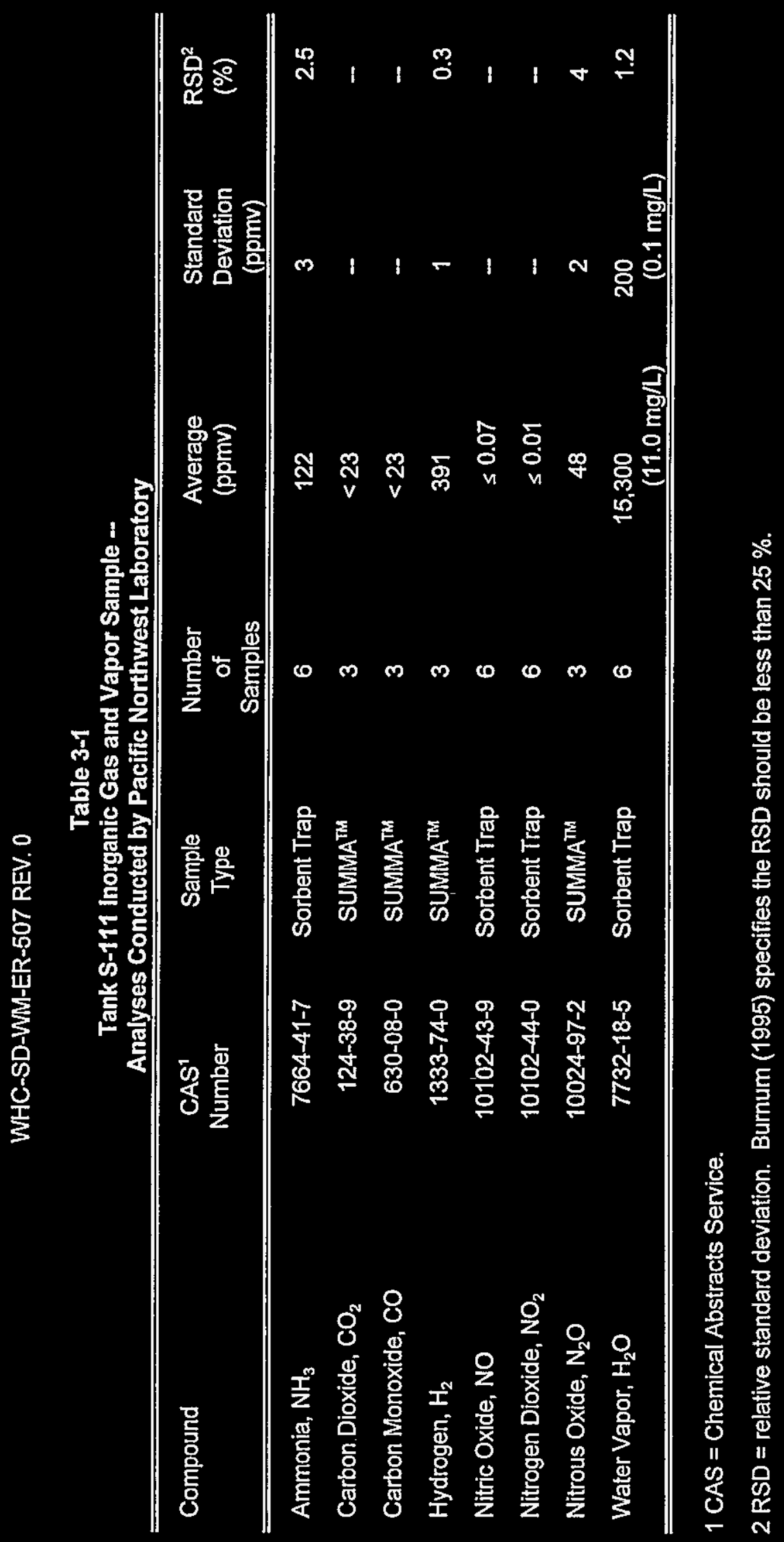


WHC-SD-WM-ER-507 REV. 0

Table 4-1

Tank S-111 Quantitatively Measured Organic Compounds in SUMMA ${ }^{\text {TM }}$ Samples -Analyses Conducted by Pacific Northwest Laboratory

\begin{tabular}{clcccc}
\hline $\begin{array}{c}\text { Cmpd } \\
\#\end{array}$ & Compound & $\begin{array}{c}\text { CAS }^{1} \\
\text { Number }\end{array}$ & $\begin{array}{c}\text { Average }^{2} \\
\text { (ppmv) }\end{array}$ & $\begin{array}{c}\text { Standard } \\
\text { Deviation } \\
\text { (ppmv) }\end{array}$ & $\begin{array}{c}\text { RSD }^{4} \\
(\%)\end{array}$ \\
\hline \hline 1 & Ethanenitrile (acetonitrile) & $75-05-8$ & 0.011 & 0.001 & 8 \\
2 & Propanone (acetone) $_{3}$ & $67-64-1$ & 0.15 & 0.02 & 16 \\
4 & Trichlorofluoromethane $_{1-P r o p a n o l}{ }^{5}$ & $75-69-4$ & 0.021 & 0.003 & 12 \\
5 & 2-Butanone & $71-23-8$ & 0.0080 & 0.0050 & - \\
6 & Tetrahydrofuran & $78-93-3$ & 0.010 & 0.002 & 20 \\
7 & Toluene & $109-99-9$ & 0.017 & 0.0001 & 1 \\
8 & Methane & $108-88-3$ & 0.022 & 0.001 & 4 \\
\hline \hline
\end{tabular}

$1 \mathrm{CAS}=$ Chemical Abstract Service.

2 Average of 3 samples.

3 When the analyte was detected in only 2 samples, the entry is the relative difference (i.e., their difference divided by 2 ).

4 RSD = relative standard deviation. Burnum (1995) specifies the RSD should be less than $25 \%$.

5 Detected in only 2 samples. 
WHC-SD-WM-ER-507 REV. 0

Table 4-2

Tank S-111 Quantitatively Measured Organic Compounds in TST Samples Analyses by Oak Ridge National Laboratory ${ }^{1}$

\begin{tabular}{clcccc}
\hline \hline $\begin{array}{c}\text { Cmpd } \\
\#\end{array}$ & Compound & $\begin{array}{c}\text { CAS }^{2} \\
\text { Number }\end{array}$ & $\begin{array}{c}\text { Average }^{3} \\
\text { (ppmv) }\end{array}$ & $\begin{array}{c}\text { Standard } \\
\text { Deviation } \\
\text { (ppmv) }\end{array}$ & $\begin{array}{c}\mathrm{RSD}^{4} \\
\text { (\%) }\end{array}$ \\
\hline \hline 1 & Ethanenitrile (acetonitrile) & $75-05-8$ & 0.021 & 0.004 & 17 \\
2 & Toluene & $108-88-3$ & 0.018 & 0.0004 & 2 \\
\hline \hline
\end{tabular}

1 Results in this table are quantitative (as defined in Section 4.1).

$2 \mathrm{CAS}=$ Chemical Abstract Service.

3 Average of 4 TST samples: 1 was $1-L$ and 3 were $4-L$.

$4 \mathrm{RSD}=$ relative standard deviation. Burnum (1995) specifies the RSD should be less than $25 \%$. 
WHC-SD-WM-ER-507 REV. 0

Table 4-3

Tank S-111 Positively Identified Organic Compounds in TST Samples -Analyses by Oak Ridge National Laboratory ${ }^{1}$

\begin{tabular}{|c|c|c|c|c|c|}
\hline$\underset{\#}{\text { Cmpd }}$ & Compound & $\begin{array}{l}\mathrm{CAS}^{2} \\
\text { Number }\end{array}$ & $\begin{array}{l}\text { Average }^{3} \\
\text { (ppmv) }\end{array}$ & $\begin{array}{c}\text { Standard } \\
\text { Deviation } \\
\text { (ppmv) }\end{array}$ & $\begin{array}{c}\mathrm{RSD}^{4} \\
(\%)\end{array}$ \\
\hline 1 & $\begin{array}{l}\text { 1,1-dichloroethene (vinylidene } \\
\text { chloride) }\end{array}$ & $75-35-4$ & 0.00017 & 0.00001 & 5 \\
\hline 2 & $\begin{array}{l}\text { Dichloremethane (methyiene } \\
\text { chloride) }\end{array}$ & $75-09-2$ & 0.00010 & - & - \\
\hline 3 & n-Propanenitrile & $107-12-0$ & 0.0015 & 0.0003 & 21 \\
\hline 4 & n-Hexane & $110-54-3$ & 0.0031 & 0.0002 & 6 \\
\hline 5 & Benzene & $71-43-2$ & 0.0030 & 0.0001 & 3 \\
\hline 6 & n-Butanenitrile & $109-74-0$ & 0.0035 & 0.0003 & 9 \\
\hline 7 & n-Heptane & $142-82-5$ & 0.0018 & 0.0001 & 4 \\
\hline 8 & 2-Hexanone & $591-78-6$ & 0.00072 & 0.00001 & 2 \\
\hline 9 & n-Octane & $111-65-9$ & 0.00066 & 0.00001 & 2 \\
\hline 10 & n-Hexanenitrile & $628-73-9$ & 0.00017 & 0.00001 & 4 \\
\hline 11 & 2-Heptanone & $110-43-0$ & 0.00072 & 0.00004 & 5 \\
\hline 12 & n-Nonane & $111-84-2$ & 0.00039 & 0.00001 & 1 \\
\hline 13 & n-Heptanenitrile & $629-08-3$ & 0.000081 & 0.000006 & 7 \\
\hline 14 & 2-Octanone & $111-13-7$ & 0.00017 & 0.00001 & 4 \\
\hline 15 & n-Decane & $124-18-5$ & 0.00034 & 0.00002 & 7 \\
\hline 16 & n-Undecane & $1120-21-4$ & 0.00024 & $0.00001^{\circ}$ & 3 \\
\hline 17 & n-Dodecane & $112-40-3$ & 0.00012 & 0.00002 & 12 \\
\hline 18 & n-Tridecane & $629-50-5$ & 0.00020 & 0.00002 & 7 \\
\hline
\end{tabular}

1 Results in this table are not quantitative (as defined in Section 4.1 ) because measured values in at least 1 of the samples are outside instrument calibration limits.

$2 \mathrm{CAS}=$ Chemical Abstract Service.

3 Average of 4 TST samples: 1 was 1-L and 3 were 4-L.

4 RSD = relative standard deviation. Burnum (1995) specifies the RSD should be less than $25 \%$. 
WHC-SD-WM-ER-507 REV. 0

Table 4-4

Tank S-111 Positively Identified Organic Compounds in TST Samples for which Practical Holding Times were Exceeded Analyses by Oak Ridge National Laboratory ${ }^{1}$

\begin{tabular}{clrrrr}
\hline $\begin{array}{c}\text { Cmpd } \\
\#\end{array}$ & Compound & $\begin{array}{c}\text { CAS }^{2} \\
\text { Number }\end{array}$ & $\begin{array}{c}\text { Average }^{3} \\
\text { (ppmv) }\end{array}$ & $\begin{array}{c}\text { Standard } \\
\text { Deviation } \\
\text { (ppmv) }\end{array}$ & $\begin{array}{c}\text { RSD }^{4} \\
(\%)\end{array}$ \\
\hline 1 & Propanone $^{5}$ (acetone) & $67-64-1$ & 0.094 & 0.011 & 11 \\
2 & Butanal $^{5}$ & $123-72-8$ & 0.013 & 0.001 & 7 \\
3 & 1-Butanol & $71-36-3$ & 0.059 & 0.005 & 9 \\
4 & 2-Pentanone & $107-87-9$ & 0.0019 & 0.0001 & 4 \\
5 & n-Pentanenitrile & $110-59-8$ & 0.00029 & 0.00004 & 13 \\
\hline \hline
\end{tabular}

1 Practical holding times are défined and discussed in Section 4.1.

$2 \mathrm{CAS}=$ Chemical Abstract Service.

3 Average of 4 TST samples: 1 was $1-L$ and 3 were $4-L$.

4 RSD = relative standard deviation. Burnum (1995) specifies the RSD should be less than $25 \%$.

5 The concentration of this analyte is quantitatively measured (as defined in Section 4.1).

6 The concentration of this analyte was not quantitatively measured (as defined in Section 4.1), because the measured concentration was outside of the instrumental calibration limits.

7 Detected in only 3 samples. 
Table 4.5

Tank S-111 Comparison of Organic Compounds in TST and SUMMA ${ }^{\text {TM }}$ Samples -Analyses by Pacific Northwest Laboratory and Oak Ridge National Laboratory

\begin{tabular}{lcccc}
\hline Compound & $\begin{array}{c}\text { CAS } \\
\text { Number }\end{array}$ & $\begin{array}{c}\text { TST } \\
\text { Average }^{2} \\
\text { (ppmv) }\end{array}$ & $\begin{array}{c}\text { SUMMA }^{\text {TM }} \\
\text { Average }^{3} \\
\text { (ppmv) }\end{array}$ & $\begin{array}{c}\text { PRD }^{4} \\
(\%)\end{array}$ \\
\hline \hline $\begin{array}{l}\text { 1,1-Dichloroethene (vinylidene chloride) } \\
\text { Dichloromethane } \\
\text { (methylene chloride) }\end{array}$ & $75-35-4$ & 0.00017 & $<0.005$ & -- \\
Propanone (acetone) & $75-09-2$ & 0.000034 & $<0.005$ & - \\
Ethanenitrile (acetonitrile) & $67-64-1$ & 0.094 & 0.15 & 46 \\
Propanenitrile & $75-05-8$ & 0.021 & 0.011 & 62 \\
n-Butanenitrile & $107-12-0$ & 0.0015 & $<0.005$ & -- \\
Benzene & $109-74-0$ & 0.0035 & $<0.005$ & - \\
Toluene & $71-43-2$ & 0.0030 & $<0.005$ & - \\
n-Hexane & $108-88-3$ & 0.018 & 0.022 & 20 \\
n-Heptane & $110-54-3$ & 0.0031 & $<0.005$ & -- \\
n-Decane & $142-82-5$ & 0.0018 & $<0.005$ & -- \\
\hline \hline
\end{tabular}

$1 \mathrm{CAS}=$ Chemical Abstract Service.

2 Average of 4 TST samples: 1 was $1-\mathrm{L}$ and 3 were $4-\mathrm{L}$ by ORNL.

3 Average of 3 samples by PNL.

$4 \mathrm{PRD}=$ percent relative difference. Keller (1994) requires the PRD to be less than $20 \%$. 
WHC-SD-WM-ER-507 REV. 0

Table 4-6

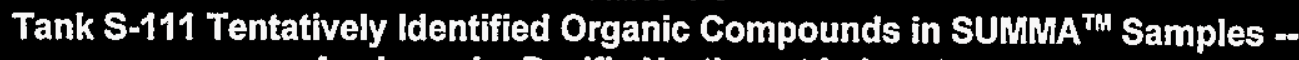
Analyses by Pacific Northwest Laboratory

\begin{tabular}{clccc}
\hline $\begin{array}{c}\text { Cmpd } \\
\#\end{array}$ & Compound & $\begin{array}{c}\mathrm{CAS}^{1} \\
\text { Number }\end{array}$ & $\begin{array}{c}\text { Average }^{2} \\
\left(\mathrm{mg} / \mathrm{m}^{3}\right)\end{array}$ & $\begin{array}{c}\text { Standard } \\
\text { Deviation } \\
\left(\mathrm{mg} / \mathrm{m}^{3}\right)\end{array}$ \\
\hline \hline 1 & Methanol (methyl alcohol) & $67-56-1$ & 0.48 & 0.04 \\
2 & Ethanol & $64-17-5$ & 0.44 & 0.01 \\
3 & Propane & $74-98-6$ & 0.19 & 0.03 \\
4 & 1-Butanol & $71-36-3$ & 0.10 & 0.02 \\
5 & n-Butane & $106-97-8$ & 0.06 & $<0.01$ \\
\hline \hline Sum of tentatively identified compounds: & & 1.27 & \\
\hline \hline
\end{tabular}

$1 \mathrm{CAS}=$ Chemical Abstract Service.

2 Average of 3 samples by PNL, values listed are estimated. 
WHC-SD-WM-ER-507 REV. 0

Table 4-7

Tank S-111 Tentatively Identified Organic Compounds in TST Samples in Order of Chromatographic Elution --

Analyses by Oak Ridge National Laboratory

\begin{tabular}{|c|c|c|c|c|}
\hline Cmpd & Compounds & $\begin{array}{l}\text { CAS }^{1} \\
\text { Number }\end{array}$ & $\begin{array}{c}\text { Average } 2 \\
\left(\mathrm{mg} / \mathrm{m}^{3}\right)\end{array}$ & $\begin{array}{l}\text { Standard } \\
\text { Deviation } \\
\left(\mathrm{mg} / \mathrm{m}^{3}\right)\end{array}$ \\
\hline 1 & 1-Propene, 2-methyl- & $115-11-7$ & 0.012 & 0.002 \\
\hline 2 & Methyl Alcohol & $67-56-1$ & 0.051 & 0.102 \\
\hline 3 & Methanol and acetone & & 0.061 & 0.070 \\
\hline 4 & Acetaldehyde and acetone & & 0.035 & 0.070 \\
\hline 5 & Propane, 2,2-dimethyl- & $463-82-1$ & 0.0032 & 0.0064 \\
\hline 6 & 1-Propene, 2-methyl- & $115-11-7$ & 0.0022 & 0.0044 \\
\hline 7 & 1-Butene & $106-98-9$ & 0.0044 & 0.0029 \\
\hline 8 & $\begin{array}{l}\text { Hydrazine, 1,1-dimethyl and nitric } \\
\text { oxide or ethane }\end{array}$ & - & 0.0039 & 0.0030 \\
\hline 9 & Ethanol & $64-17-5$ & 0.25 & 0.04 \\
\hline 10 & Trichloromonofluoromethane & $75-69-4$ & 0.038 & 0.016 \\
\hline 11 & Silane, chlorotrimethyl- & $75-77-4$ & 0.012 & 0.020 \\
\hline 12 & Isopropyl Alcohol & $67-63-0$ & 0.037 & 0.006 \\
\hline 13 & Alkane & & 0.0046 & 0.0031 \\
\hline 14 & 1-Propanol & $71-23-8$ & 0.014 & 0.010 \\
\hline 15 & $\begin{array}{l}\text { Benzenemethanol, alpha, methyl- } \\
\text { and 1-propanol }\end{array}$ & & 0.0064 & 0.0128 \\
\hline 16 & 2-Butanone & $78-93-3$ & 0.016 & 0.004 \\
\hline 17 & 1-Pentene, 4-methyl- & $691-37-2$ & 0.00071 & 0.00143 \\
\hline 18 & Furan, tetrahydro- & $109-99-9$ & 0.030 & 0.005 \\
\hline 19 & Silane, dimethoxydimethyl- & $1112-39-6$ & 0.0029 & 0.0058 \\
\hline 20 & Acetic acid and others & & 0.0063 & 0.0078 \\
\hline 21 & 2-Butanone, 3-methyl- & $563-80-4$ & 0.0020 & 0.0023 \\
\hline 22 & 1H-Pyrazole, 3-methyl- & $1453-58-3$ & 0.0031 & 0.0021 \\
\hline 23 & 2-Butanone, 3,3-dimethyl- & $75-97-8$ & 0.012 & 0.001 \\
\hline 24 & Pyrazine & $290-37-9$ & 0.042 & 0.006 \\
\hline
\end{tabular}




\begin{tabular}{|c|c|c|c|c|}
\hline$\underset{\#}{\text { Cmpd }}$ & Compounds & $\begin{array}{l}\text { CAS }^{1} \\
\text { Number }\end{array}$ & $\begin{array}{c}\text { Average }^{2} \\
\left(\mathrm{mg} / \mathrm{m}^{3}\right)\end{array}$ & $\begin{array}{c}\text { Standard } \\
\text { Deviation } \\
\left(\mathrm{mg} / \mathrm{m}^{3}\right)\end{array}$ \\
\hline 25 & Propane, 2-methyl-2-nitro- & $594-70-7$ & 0.0094 & 0.0027 \\
\hline 26 & N-Nitrosodimethylamine & $62-75-9$ & 0.034 & 0.010 \\
\hline 27 & Pyridine, 3,4-dimethyl- & $583-58-4$ & 0.0018 & 0.0036 \\
\hline 28 & Furan, 2,3-dihydro & $1191-99-7$ & 0.0064 & 0.0026 \\
\hline 29 & Benzothiazole, 2-phenyl- & $883-93-2$ & 0.0059 & 0.0103 \\
\hline 30 & 2-Pentanone, 4,4-dimethyl- & $590-50-1$ & 0.0026 & 0.0018 \\
\hline 31 & Aziridine, 2-ethyl- & $2549-67-9$ & 0.015 & 0.009 \\
\hline 32 & Tetrachloroethylene & $127-18-4$ & 0.0031 & 0.0021 \\
\hline 33 & Cyclotrisiloxane, hexamethyl- & $541-05-9$ & 0.038 & 0.037 \\
\hline 34 & Pyrazine, methyl- & $109-08-0$ & 0.0018 & 0.0023 \\
\hline 35 & Oxazole, 4,5-dihydro-2-methyl- & $1120-64-5$ & 0.0018 & 0.0013 \\
\hline 36 & Ethylbenzene & $100-41-4$ & 0.0036 & 0.0010 \\
\hline 37 & Oxirane, (1-methylbutyl)- & $53229-39-3$ & 0.0018 & 0.0012 \\
\hline 38 & Benzene, 1,3-dimethyl- & $108-38-3$ & 0.0090 & 0.0014 \\
\hline 39 & $\begin{array}{l}\text { Propane, } 2-[(1,1-\text { dimethylethyl) } \\
\text { sulfonyl]-2-methyl- }\end{array}$ & $1886-75-5$ & 0.0035 & 0.0030 \\
\hline 40 & 3-Heptanone & $106-35-4$ & 0.0076 & 0.0005 \\
\hline 41 & Benzene, 1,3-dimethyl- & $108-38-3$ & 0.0073 & 0.0002 \\
\hline 42 & Pyrazine, 2,5-dimethyl- & $123-32-0$ & 0.00093 & 0.00108 \\
\hline 43 & 2-Heptanone, 6-methyl- & $928-68-7$ & 0.0067 & 0.0021 \\
\hline 44 & Cyclohexanol & $108-93-0$ & 0.00055 & 0.00110 \\
\hline 45 & Benzaldehyde & $100-52-7$ & 0.0045 & 0.0034 \\
\hline 46 & Cyclotetrasiloxane, octamethyl- & $556-67-2$ & 0.021 & 0.016 \\
\hline 47 & 2H-Pyran-2-one, 6-hexyltetrahydro- & $710-04-3$ & 0.00067 & 0.00134 \\
\hline 48 & 1,2,4-Trimethylbenzene & $95-63-6$ & 0.0018 & 0.0012 \\
\hline 49 & Decane, 4-methyl- & $2847-72-5$ & 0.00095 & 0.00109 \\
\hline 50 & 1-Hexanol, 2-ethyl- & $104-76-7$ & 0.0018 & 0.0012 \\
\hline 51 & Benzyl Alcohol & $100-51-6$ & 0.0021 & 0.0014 \\
\hline 52 & Mixture & & 0.0017 & 0.0011 \\
\hline
\end{tabular}


WHC-SD-WM-ER-507 REV. 0

\begin{tabular}{clccc}
\hline $\begin{array}{c}\text { Cmpd } \\
\#\end{array}$ & Compounds & $\begin{array}{c}\mathrm{CAS}^{1} \\
\text { Number }\end{array}$ & $\begin{array}{c}\text { Average } \\
\left(\mathrm{mg} / \mathrm{m}^{3}\right)\end{array}$ & $\begin{array}{c}\text { Standard } \\
\text { Deviation } \\
\left(\mathrm{mg} / \mathrm{m}^{3}\right)\end{array}$ \\
\hline \hline 53 & 2 (3H)-Furanone, 5-ethyldihydro- & $\begin{array}{c}695-06-7 \\
124-19-6\end{array}$ & 0.00055 & 0.00110 \\
54 & Nonanal & 0.00040 & 0.00080 \\
56 & $\begin{array}{l}\text { Benzoic acid, 2-I(trimethylsilyl)oxy]-, } \\
\text { trimethyl ester }\end{array}$ & $3789-85-3$ & 0.010 & 0.013 \\
57 & $\begin{array}{l}2(3 \mathrm{H})-F u r a n o n e, ~ \\
\text { dihydro-5-propyl- }\end{array}$ \\
58 & $\begin{array}{l}\text { Tetradecane } \\
59\end{array}$ & $105-21-5$ & 0.00095 & 0.00111 \\
60 & $\begin{array}{l}\text { Heptanoic acid, butyl ester } \\
61\end{array}$ & $629-59-4$ & 0.00044 & 0.00087 \\
62 & Benzenesulfonamide, N-butyl- & $2051-60-7$ & 0.00042 & 0.00083 \\
\hline \hline Sum of tentatively identified compounds: & $5454-28-4$ & 0.00074 & 0.00148 \\
\hline \hline
\end{tabular}

$1 \mathrm{CAS}=$ Chemical Abstract Service

2 Average of 4 TST samples; 1 was $1-L$ and 3 were $4-L$, values listed are estimated. 
WHC-SD-WM-ER-507 REV. 0

Table 4-8

Tank S-111 Tentatively Identified Organic Compounds in TST Samples

Sorted Alphanumerically -Analyses by Oak Ridge National Laboratory

\begin{tabular}{|c|c|c|c|c|}
\hline$\underset{\#}{\text { Cmpd }}$ & Compounds & $\begin{array}{l}\text { CAS }^{1} \\
\text { Number }\end{array}$ & $\begin{array}{l}\text { Average } 2 \\
\left(\mathrm{mg} / \mathrm{m}^{3}\right)\end{array}$ & $\begin{array}{c}\text { Standard } \\
\text { Deviation } \\
\left(\mathrm{mg} / \mathrm{m}^{3}\right)\end{array}$ \\
\hline 1 & 1-Propene, 2-methyl- & $115-11-7$ & 0.012 & 0.002 \\
\hline 17 & 1-Pentene, 4-methyl- & $691-37-2$ & 0.00071 & 0.00143 \\
\hline 14 & 1-Propanol & $71-23-8$ & 0.014 & 0.010 \\
\hline 50 & 1-Hexanol, 2-ethyl- & $104-76-7$ & 0.0018 & 0.0012 \\
\hline 7 & 1-Butene & $106-98-9$ & 0.0044 & 0.0029 \\
\hline 6 & 1-Propene, 2-methyl- & $115-11-7$ & 0.0022 & 0.0044 \\
\hline 59 & 1,1'-Biphenyl, 2-chloro- & $2051-60-7$ & 0.00042 & 0.00083 \\
\hline 55 & $\begin{array}{l}\text { 1,2-Bis(trimethylsilyl)-4,5-dimethyl- } \\
\text { cyclohexa-1,4-diene }\end{array}$ & & 0.0016 & 0.0031 \\
\hline 48 & 1,2,4-Trimethylbenzene & $95-63-6$ & 0.0018 & 0.0012 \\
\hline 22 & 1H-Pyrazole, 3-methyl- & $1453-58-3$ & 0.0031 & 0.0021 \\
\hline 21 & 2-Butanone, 3-methyl- & $563-80-4$ & 0.0020 & 0.0023 \\
\hline 30 & 2-Pentanone, 4,4-dimethyl- & $590-50-1$ & 0.0026 & 0.0018 \\
\hline 23 & 2-Butanone, 3,3-dimethyl- & $75-97-8$ & 0.012 & 0.001 \\
\hline 43 & 2-Heptanone, 6-methyl- & $928-68-7$ & 0.0067 & 0.0021 \\
\hline 16 & 2-Butanone & $78-93-3$ & 0.016 & 0.004 \\
\hline 53 & 2(3H)-Furanone, 5-ethyldihydro- & $695-06-7$ & 0.00055 & 0.00110 \\
\hline 57 & $\begin{array}{l}\text { 2(3H)-Furanone, } \\
\text { dihydro-5-propyl- }\end{array}$ & $105-21-5$ & 0.00095 & 0.00111 \\
\hline 47 & 2H-Pyran-2-one, 6-hexyltetrahydro- & $710-04-3$ & 0.00067 & 0.00134 \\
\hline 40 & 3-Heptanone & $106-35-4$ & 0.0076 & 0.0005 \\
\hline 4 & Acetaldehyde and acetone & & 0.035 & 0.070 \\
\hline 20 & Acetic acid and others & & 0.0063 & 0.0078 \\
\hline 13 & Alkane & & 0.0046 & 0.0031 \\
\hline 31 & Aziridine, 2-ethyi- & $2549-67-9$ & 0.015 & 0.009 \\
\hline 45 & Benzaldehyde & $100-52-7$ & 0.0045 & 0.0034 \\
\hline
\end{tabular}




\begin{tabular}{|c|c|c|c|c|}
\hline Cmpd & Compounds & $\begin{array}{l}\mathrm{CAS}^{1} \\
\text { Number }\end{array}$ & $\begin{array}{c}\text { Average }^{2} \\
\left(\mathrm{mg} / \mathrm{m}^{3}\right)\end{array}$ & $\begin{array}{c}\text { Standard } \\
\text { Deviation } \\
\left(\mathrm{mg} / \mathrm{m}^{3}\right)\end{array}$ \\
\hline 38 & Benzene, 1,3-dimethyl- & $108-38-3$ & 0.0090 & 0.0014 \\
\hline 41 & Benzene, 1,3-dimethyl- & $108-38-3$ & 0.0073 & 0.0002 \\
\hline 15 & $\begin{array}{l}\text { Benzenemethanol, alpha, methyl- } \\
\text { and 1-propanol }\end{array}$ & & 0.0064 & 0.0128 \\
\hline 61 & Benzenesulfonamide, N-butyl- & $3622-84-2$ & 0.0082 & 0.0055 \\
\hline 56 & $\begin{array}{l}\text { Benzoic acid, 2-[(trimethylsilyl)oxy]-, } \\
\text { trimethyl ester }\end{array}$ & $3789-85-3$ & 0.010 & 0.013 \\
\hline 29 & Benzothiazole, 2-phenyl- & $883-93-2$ & 0.0059 & 0.0103 \\
\hline 51 & Benzyl Alcohol & $100-51-6$ & 0.0021 & 0.0014 \\
\hline 44 & Cyclohexanol & $108-93-0$ & 0.00055 & 0.00110 \\
\hline 46 & Cyclotetrasiloxane, octamethyl- & $556-67-2$ & 0.021 & 0.016 \\
\hline 33 & Cyclotrisiloxane, hexamethyl- & $541-05-9$ & 0.038 & 0.037 \\
\hline 49 & Decane, 4-methyl- & $2847-72-5$ & 0.00095 & 0.00109 \\
\hline 9 & Ethanol & $64-17-5$ & 0.25 & .0 .04 \\
\hline 36 & Ethylbenzene & $100-41-4$ & 0.0036 & 0.0010 \\
\hline 18 & Furan, tetrahydro- & $109-99-9$ & 0.030 & 0.005 \\
\hline 28 & Furan, 2,3-dihydro- & $1191-99-7$ & 0.0064 & 0.0026 \\
\hline 60 & Heptanoic acid, butyl ester & $5454-28-4$ & 0.00074 & 0.00148 \\
\hline 8 & $\begin{array}{l}\text { Hydrazine, 1,1-dimethyl and nitric } \\
\text { oxide or ethane }\end{array}$ & & 0.0039 & 0.0030 \\
\hline 12 & Isopropyl Alcohol & $67-63-0$ & 0.037 & 0.006 \\
\hline 62 & Isopropyl Palmitate & $142-91-6$ & 0.00042 & 0.00084 \\
\hline 3 & Methanol and acetone & & 0.061 & 0.070 \\
\hline 2 & Methyl Alcohol & $67-56-1$ & 0.051 & 0.102 \\
\hline 52 & Mixture & & 0.0017 & 0.0011 \\
\hline 26 & $\mathrm{~N}$-Nitrosodimethylamine & $62-75-9$ & 0.034 & 0.010 \\
\hline 54 & Nonanal & $124-19-6$ & 0.00040 & 0.00080 \\
\hline 35 & Oxazole, 4,5-dihydro-2-methyl- & $1120-64-5$ & 0.0018 & 0.0013 \\
\hline 37 & Oxirane, (1-methylbutyl)- & $53229-39-3$ & 0.0018 & 0.0012 \\
\hline \multicolumn{5}{|c|}{27} \\
\hline
\end{tabular}




\begin{tabular}{clccc}
\hline $\begin{array}{c}\text { Cmpd } \\
\#\end{array}$ & Compounds & $\begin{array}{c}\text { CAS }^{1} \\
\text { Number }\end{array}$ & $\begin{array}{c}\text { Average } \\
\left(\mathrm{mg} / \mathrm{m}^{3}\right)\end{array}$ & $\begin{array}{c}\text { Standard } \\
\text { Deviation } \\
\left(\mathrm{mg} / \mathrm{m}^{3}\right)\end{array}$ \\
\hline 5 & Propane, 2,2-dimethyl- & $463-82-1$ & 0.0032 & 0.0064 \\
25 & Propane, 2-methyl-2-nitro- & $594-70-7$ & 0.0094 & 0.0027 \\
39 & $\begin{array}{l}\text { Propane, 2-[(1,1-dimethylethyl) } \\
\text { sulfonyl]-2-methyl- }\end{array}$ & $1886-75-5$ & 0.0035 & 0.0030 \\
24 & Pyrazine & $290-37-9$ & 0.042 & 0.006 \\
34 & Pyrazine, methyl- & $109-08-0$ & 0.0018 & 0.0023 \\
42 & Pyrazine, 2,5-dimethyl- & $123-32-0$ & 0.00093 & 0.00108 \\
27 & Pyridine, 3,4-dimethyl- & $583-58-4$ & 0.0018 & 0.0036 \\
11 & Silane, chlorotrimethyl- & $75-77-4$ & 0.012 & 0.020 \\
19 & Silane, dimethoxydimethyl- & $1112-39-6$ & 0.0029 & 0.0058 \\
32 & Tetrachloroethylene & $127-18-4$ & 0.0031 & 0.0021 \\
58 & Tetradecane & $629-59-4$ & 0.00044 & 0.00087 \\
10 & Trichloromonofluoromethane & $75-69-4$ & 0.038 & 0.016 \\
\hline \hline Sum of tentatively identified compounds: & & 0.87 & \\
\hline \hline
\end{tabular}

$1 \mathrm{CAS}=$ Chemical Abstract Service.

2 Average of 4 TST samples; 1 was 1-L and 3 were 4-L, values listed are estimated. 
WHC-SD-WM-ER-507 REV. 0

Table 4-9

Tank S-111 Tentatively Identified Organic Compounds in TST Samples

Sorted by estimated Concentration --

Analyses by Oak Ridge National Laboratory

\begin{tabular}{|c|c|c|c|c|}
\hline$\underset{\#}{\text { Cmpd }}$ & Compounds & $\begin{array}{l}\text { CAS }^{1} \\
\text { Number }\end{array}$ & $\begin{array}{l}\text { Average }^{2} \\
\left(\mathrm{mg} / \mathrm{m}^{3}\right)\end{array}$ & $\begin{array}{c}\text { Standard } \\
\text { Deviation } \\
\left(\mathrm{mg} / \mathrm{m}^{3}\right)\end{array}$ \\
\hline 9 & Ethanol & $64-17-5$ & 0.25 & 0.04 \\
\hline 3 & Methanol and acetone & & 0.061 & 0.070 \\
\hline 2 & Methyl Alcohol & $67-56-1$ & 0.051 & 0.102 \\
\hline 24 & Pyrazine & $290-37-9$ & 0.042 & 0.006 \\
\hline 10 & Trichloromonofluoromethane & $75-69-4$ & 0.038 & 0.016 \\
\hline 33 & Cyclotrisiloxane, hexamethyl- & $541-05-9$ & 0.038 & 0.037 \\
\hline 12 & Isopropyl Alcohol & $67-63-0$ & 0.037 & 0.006 \\
\hline 4 & Acetaldehyde and acetone & & 0.035 & 0.070 \\
\hline 26 & N-Nitrosodimethylamine & $62-75-9$ & 0.034 & 0.010 \\
\hline 18 & Furan, tetrahydro- & $109-99-9$ & 0.030 & 0.005 \\
\hline 46 & Cyclotetrasiloxane, octamethyl- & $556-67-2$ & 0.021 & 0.016 \\
\hline 16 & 2-Butanone & 78-93-3 & 0.016 & 0.004 \\
\hline 31 & Aziridine, 2-ethyl- & $2549-67-9$ & 0.015 & 0.009 \\
\hline 14 & 1-Propanol & $71-23-8$ & 0.014 & 0.010 \\
\hline 11 & Silane, chlorotrimethyl- & $75-77-4$ & 0.012 & 0.020 \\
\hline 1 & 1-Propene, 2-methyl- & $115-11-7$ & 0.012 & 0.002 \\
\hline 23 & 2-Butanone, 3,3-dimethyl- & $75-97-8$ & 0.012 & 0.001 \\
\hline 56 & $\begin{array}{l}\text { Benzoic acid, 2-\{(trimethylsilyl)oxy]-, } \\
\text { trimethyl ester }\end{array}$ & $3789-85-3$ & 0.010 & 0.013 \\
\hline 25 & Propane, 2-methyl-2-nitro- & $594-70-7$ & 0.0094 & 0.0027 \\
\hline 38 & Benzene, 1,3-dimethyl- & $108-38-3$ & 0.0090 & 0.0014 \\
\hline 61 & Benzenesulfonamide, N-butyl- & $3622-84-2$ & 0.0082 & 0.0055 \\
\hline 40 & 3-Heptanone & $106-35-4$ & 0.0076 & 0.0005 \\
\hline 41 & Benzene, 1,3-dimethyl- & $108-38-3$ & 0.0073 & 0.0002 \\
\hline 43 & 2-Heptanone, 6-methyl- & $928-68-7$ & 0.0067 & 0.0021 \\
\hline
\end{tabular}


WHC-SD-WM-ER-507 REV. 0

\begin{tabular}{|c|c|c|c|c|}
\hline$\underset{\#}{\text { Cmpd }}$ & Compounds & $\begin{array}{l}\text { CAS }^{1} \\
\text { Number }\end{array}$ & $\begin{array}{l}\text { Average }^{2} \\
\left(\mathrm{mg} / \mathrm{m}^{3}\right)\end{array}$ & $\begin{array}{c}\text { Standard } \\
\text { Deviation } \\
\left(\mathrm{mg} / \mathrm{m}^{3}\right) \\
\end{array}$ \\
\hline 15 & $\begin{array}{l}\text { Benzenemethanol, alpha, methyl- } \\
\text { and 1-propanol }\end{array}$ & & 0.0064 & 0.0128 \\
\hline 28 & Furan, 2,3-dihydro- & $1191-99-7$ & 0.0064 & 0.0026 \\
\hline 20 & Acetic acid and others & & 0.0063 & 0.0078 \\
\hline 29 & Benzothiazole, 2-phenyl- & $883-93-2$ & 0.0059 & 0.0103 \\
\hline 13 & Alkane & & 0.0046 & 0.0031 \\
\hline 45 & Benzaldehyde & $100-52-7$ & 0.0045 & 0.0034 \\
\hline 7 & 1-Butene & $106-98-9$ & 0.0044 & 0.0029 \\
\hline 8 & $\begin{array}{l}\text { Hydrazine, 1,1-dimethyl- and nitric } \\
\text { oxide or ethane }\end{array}$ & & 0.0039 & 0.0030 \\
\hline 36 & Ethylbenzene & $100-41-4$ & 0.0036 & 0.0010 \\
\hline 39 & $\begin{array}{l}\text { Propane, 2-[(1,1-dimethylethyl) } \\
\text { sulfonyl]-2-methyl- }\end{array}$ & $1886-75-5$ & 0.0035 & 0.0030 \\
\hline 5 & Propane, 2,2-dimethyl- & $463-82-1$ & 0.0032 & 0.0064 \\
\hline 22 & 1H-Pyrazole, 3-methyl- & $1453-58-3$ & 0.0031 & 0.0021 \\
\hline 32 & Tetrachloroethylene & $127-18-4$ & 0.0031 & 0.0021 \\
\hline 19 & Silane, dimethoxydimethyl- & $1112-39-6$ & 0.0029 & 0.0058 \\
\hline 30 & 2-Pentanone, 4,4-dimethyl- & $590-50-1$ & 0.0026 & 0.0018 \\
\hline 6 & 1-Propene, 2-methyl- & $115-11-7$ & 0.0022 & 0.0044 \\
\hline 51 & Benzyl Alcohol & $100-51-6$ & 0.0021 & 0.0014 \\
\hline 21 & 2-Butanone, 3-methyl- & $563-80-4$ & 0.0020 & 0.0023 \\
\hline 35 & Oxazole, 4,5-dihydro-2-methyl- & $1120-64-5$ & 0.0018 & 0.0013 \\
\hline 34 & Pyrazine, methyl- & $109-08-0$ & 0.0018 & 0.0023 \\
\hline 27 & Pyridine, 3,4-dimethyl- & $583-58-4$ & 0.0018 & 0.0036 \\
\hline 37 & Oxirane, (1-methylbutyl)- & $53229-39-3$ & 0.0018 & 0.0012 \\
\hline 50 & 1-Hexanol, 2-ethyl- & $104-76-7$ & 0.0018 & 0.0012 \\
\hline 48 & 1,2,4-Trimèthylbenzene & $95-63-6$ & 0.0018 & 0.0012 \\
\hline 52 & Mixture & & 0.0017 & 0.0011 \\
\hline 55 & $\begin{array}{l}\text { 1,2-Bis(trimethylsilyl)-4,5-dimethyl- } \\
\text { cyclohexa-1,4-diene }\end{array}$ & & 0.0016 & 0.0031 \\
\hline
\end{tabular}


WHC-SD-WM-ER-507 REV. 0

\begin{tabular}{|c|c|c|c|c|}
\hline$\underset{\#}{\text { Cmpd }}$ & Compounds & $\begin{array}{l}\text { CAS }^{1} \\
\text { Number }\end{array}$ & $\begin{array}{c}\text { Average }^{2} \\
\left(\mathrm{mg} / \mathrm{m}^{3}\right)\end{array}$ & $\begin{array}{c}\text { Standard } \\
\text { Deviation } \\
\left(\mathrm{mg} / \mathrm{m}^{3}\right)\end{array}$ \\
\hline 49 & Decane, 4-methyl- & $2847-72-5$ & 0.00095 & 0.00109 \\
\hline 57 & 2(3H)-Furanone, dihydro-5-propyl- & $105-21-5$ & 0.00095 & 0.00111 \\
\hline 42 & Pyrazine, 2,5-dimethyl- & $123-32-0$ & 0.00093 & 0.00108 \\
\hline 17 & 1-Pentene, 4-methyl- & $691-37-2$ & 0.00071 & 0.00143 \\
\hline 60 & Heptanoic acid, butyl ester & $5454-28-4$ & 0.00074 & 0.00148 \\
\hline 47 & 2H-Pyran-2-one, 6-hexyltetrahydro- & $710-04-3$ & 0.00067 & 0.00134 \\
\hline 53 & 2(3H)-Furanone, 5-ethyldihydro- & $695-06-7$ & 0.00055 & 0.00110 \\
\hline 44 & Cyclohexanol & $108-93-0$ & 0.00055 & 0.00110 \\
\hline 59 & 1,1'-Biphenyl, 2-chloro- & $2051-60-7$ & 0.00042 & 0.00083 \\
\hline 58 & Tetradecane & $629-59-4$ & 0.00044 & 0.00087 \\
\hline 54 & 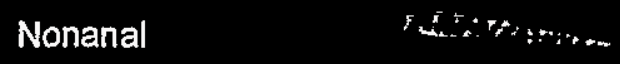 & $124-19-6$ & 0.00040 & 0.00080 \\
\hline 62 & Isopropyl Paimitate & $142-91-6$ & 0.00042 & 0.00084 \\
\hline \multicolumn{3}{|c|}{ Sum of tentatively identified compounds: } & 0.87 & \\
\hline
\end{tabular}

$1 \mathrm{CAS}=$ Chemical Abstract Service .

2 Average of 4 TST samples; 1 was $1-\mathrm{L}$ and 3 were $4-\mathrm{L}$, values listed are estimates. 
